\title{
Single-neuron diversity generated by Protocadherin- $\beta$ cluster in mouse central and peripheral nervous systems
}

\author{
Keizo Hirano ${ }^{1+}$, Ryosuke Kaneko ${ }^{1,2+}$, Takeshi Izawa ${ }^{1}$, Masahumi Kawaguchi ${ }^{1,3}$, Takashi Kitsukawa ${ }^{1,4}$ \\ and Takeshi Yagi ${ }^{1,4 *}$ \\ KOKORO-Biology Group, Laboratories for Integrated Biology, Graduate School of Frontier Biosciences, Osaka University, 1-3 Yamadaoka, Suita, Osaka \\ 565-0871, Japan \\ 2 Institute of Experimental Animal Research, Gunma University Graduate School of Medicine, 3-39-22 Showa-machi, Maebashi, Gunma 371-8511, Japan \\ ${ }^{3}$ Department of Ultrastructural Research, National Institute of Neuroscience, Kodaira, Tokyo 187-8551, Japan \\ ${ }^{4}$ CREST, Osaka University, 1-3 Yamadaoka, Suita, Osaka 565-0871, Japan
}

\section{Edited by:}

Alistair N. Garratt, Max Delbrück Center for Molecular Medicine, Germany

Reviewed by:

Sheriar Hormuzdi, University of Dundee, UK

Alistair N. Garratt, Max Delbrück Center for Molecular Medicine,

Germany

\section{*Correspondence:}

Takeshi Yagi, Graduate School of Frontier Biosciences, Osaka

University, 1-3 Yamadaoka, Suita,

Osaka 565-0871, Japan.

e-mail: yagi@fbs.osaka-u.ac.jp

tThese authors equally contributed to this work.
The generation of complex neural circuits depends on the correct wiring of neurons with diverse individual characteristics. To understand the complexity of the nervous system, the molecular mechanisms for specifying the identity and diversity of individual neurons must be elucidated. The clustered protocadherins (Pcdh) in mammals consist of approximately 50 Pcdh genes (Pcdh- $\alpha, P c d h-\beta$, and Pcdh- $\gamma$ ) that encode cadherin-family cell surface adhesion proteins. Individual neurons express a random combination of Pcdh- $\alpha$ and $P c d h-\gamma$, whereas the expression patterns for the $P c d h-\beta$ genes, 22 one-exon genes in mouse, are not fully understood. Here we show that the $P_{c} d h-\beta$ genes are expressed in a 3'-polyadenylated form in mouse brain. In situ hybridization using a pan- $P c d h-\beta$ probe against a conserved $P c d h-\beta$ sequence showed widespread labeling in the brain, with prominent signals in the olfactory bulb, hippocampus, and cerebellum. In situ hybridization with specific probes for individual $P c d h-\beta$ genes showed their expression to be scattered in Purkinje cells from P10 to P150. The scattered expression patterns were confirmed by performing a newly developed single-cell 3'-RACE analysis of Purkinje cells, which clearly demonstrated that the $P c d h-\beta$ genes are expressed monoallelically and combinatorially in individual Purkinje cells. Scattered expression patterns of individual Pcdh- $\beta$ genes were also observed in pyramidal neurons in the hippocampus and cerebral cortex, neurons in the trigeminal and dorsal root ganglion, GABAergic interneurons, and cholinergic neurons. Our results extend previous observations of diversity at the single-neuron level generated by $P c d h$ expression and suggest that the $P c d h-\beta$ cluster genes contribute to specifying the identity and diversity of individual neurons.

\section{Keywords: single-neuron diversity, neuronal individuality, protocadherin, Pcdh, monoallelic, combinatorial} expression, single-cell $3^{\prime}$-RACE, neural circuit

\section{INTRODUCTION}

The central and peripheral nervous systems contain an enormous number of neurons, that have diverse characteristics and unique identities that enable them to generate complex neural circuits. Therefore, elucidating the molecular mechanisms that specify the unique characteristics of individual neurons is important for understanding the overall complexity of the nervous system.

Recent studies reported that two families of cell-cell recognition molecules, Dscam1 in insects and clustered protocadherin $(P c d h)$ in vertebrates, are promising candidates for specifying the unique characteristics of individual neurons (Zipursky and Sanes, 2010; Yagi, 2012). Dscam1 proteins are single-pass transmembrane domain proteins of the immunoglobulin superfamily that play important roles in neural circuit formation (Hattori et al., 2008; Schmucker and Chen, 2009). The fly Dscam 1 gene encodes 19,008 different ectodomain isoforms, which are expressed in a biased stochastic fashion in individual neurons, thereby conferring a unique molecular identity on each Drosophila neuron
(Neves et al., 2004). In addition, Hattori et al. (2007) showed that Dscam 1 diversity is essential for generating complex neural circuits.

Approximately 100 of the diverse cadherin-superfamily genes are highly expressed in vertebrate brain (Takeichi, 2007; Yagi, 2008), and about 50 of these are encoded by the $P c d h$ gene clusters, $P c d h-\alpha, P c d h-\beta$, and $P c d h-\gamma$ (Kohmura et al., 1998; Wu and Maniatis, 1999; Sugino et al., 2000; Hirayama and Yagi, 2006; Morishita and Yagi, 2007). Cadherin-superfamily proteins play key roles in the morphogenesis and function of the brain, including the formation and maintenance of the neuroepithelium, neurite extension, migration of neuronal cells, synaptogenesis, and synaptic plasticity (Takeichi, 2007; Suzuki and Takeichi, 2008). Previous studies revealed that the clustered Pcdhs play important roles in neuronal survival, axonal projection, synaptic connectivity, and several brain functions, including learning and memory (Wang et al., 2002b; Fukuda et al., 2008; Hasegawa et al., 2008; Katori et al., 2009). Since the clustered Pcdhs show 
unique gene regulations and form heteromultimeric Pcdh protein tetramers with homophilic binding specificity, the clustered Pcdhs are considered to be candidates for generating complex neural circuitry by providing molecular codes that determine neuronal individuality in the vertebrate central and peripheral nervous systems (Schreiner and Weiner, 2010; Zipursky and Sanes, 2010; Yagi, 2012).

The $P c d h-\alpha, P c d h-\beta$, and $P c d h-\gamma$ gene clusters are tandemly localted on the mouse 18 chromosome. All isoforms of $P c d h-\alpha$, $P c d h-\beta$, and $P c d h-\gamma$ genes possess their own promoters and variable exons in each gene cluster in the same direction (Wu et al., 2001). The $P c d h-\alpha$ or $P c d h-\gamma$ variable exons are spliced onto each $P c d h-\alpha$ or $P c d h-\gamma$ constant exons, respectively, that encode the common $3^{\prime}$ regions. In contrast, the $P c d h-\beta$ gene cluster does not contain constant exons and is instead comprised of unspliced single exon genes.

Extensive investigation of the gene regulation mechanisms in the clustered Pcdhs has identified some unique features. In situ hybridization analysis showed that the $P c d h-\alpha$ and $P c d h-\gamma$ genes are differentially regulated at the level of individual neurons (Kohmura et al., 1998; Esumi et al., 2005; Frank et al., 2005), and single-cell analysis of Purkinje cells using multiplex RT-PCRs established that one or two variable exons in the $P c d h-\alpha$ and $P c d h-\gamma$ clusters are stochastically expressed from each allele in individual Purkinje cells (Esumi et al., 2005; Kaneko et al., 2006). The expression of the clustered $P c d h$ genes is governed by the activation of individual promoters from among multiple promoters in the cluster (Tasic et al., 2002; Wang et al., 2002a). Furthermore, the discovery of a long-range regulatory element in the Pcdh- $\alpha$ (Ribich et al., 2006; Kehayova et al., 2011) and Pcdh- $\beta$ (Yokota et al., 2011) gene clusters provided further support for a model in which promoter choice among multiple promoters drives unique expression patterns in single neurons.

A number of transcription factors or DNA-binding proteins have been implicated in the regulation of clustered $P c d h$ gene transcription: that is, CTCF (Golan-Mashiach et al., 2012; Hirayama et al., 2012; Monahan et al., 2012), NRSF/REST (Tan et al., 2010; Kehayova et al., 2011), SOX4 (Castillo et al., 2012), Mecp2 (Chahrour et al., 2008; Miyake et al., 2011), Egr-1 (Schippert et al., 2009), and Nipbl (Kawauchi et al., 2009). In addition, $P c d h$ promoter CpG methylation is inversely correlated with Pcdh expression (Tasic et al., 2002; Kawaguchi et al., 2008; Dallosso et al., 2009, 2012; Kaneko et al., 2009). These results are consistent with the idea that the $P c d h$ cluster genes and their sophisticated gene regulation mechanisms could be involved in establishing the unique molecular identities of individual neurons in the brain (Chess, 2005; Zipursky and Sanes, 2010; Yagi, 2012). Although the regulatory mechanisms for generating Pcdh diversity at the single-neuron level have been addressed to some extent, whether this diversity contributes to the functional complexity of the mammalian nervous system remains to be determined.

To date, little information has been published on the expression of the Pcdh- $\beta$ genes, which consist of 22 single exon genes located on mouse chromosome 18 (Vanhalst et al., 2001), although the postsynaptic localization of one $\operatorname{Pcdh}-\beta$ protein, Pcdh- $\beta 16$, was reported for mouse and primate retina (Junghans et al., 2008; Puller and Haverkamp, 2011). Here, we show that the expression patterns of the $P c d h-\beta$ genes are similar to those of the $P c d h-\alpha$ and $P c d h-\gamma$ genes. $3^{\prime}$-RACE analysis of single Purkinje cells showed that $P c d h-\beta$ isoforms derived from monoallelic chromosomes were combinatorially expressed in individual Purkinje cells. Furthermore, in situ hybridization analysis showed, for the first time, scattered expression patterns at the level of individual neurons in the trigeminal ganglion, dorsal root ganglion, GABAergic interneurons, and cholinergic neurons. Our results extend previous findings on the single-neuron diversity generated by $P c d h$ expression and suggest that $P c d h-\beta$ cluster genes may contribute to specifying the identity and diversity of individual neurons.

\section{MATERIALS AND METHODS ANIMALS}

C57BL/6 (B6) mice were purchased from Charles River Japan. F1 hybrid offspring were obtained by intercrossing mice of the laboratory strain B6 with the Japanese wild mouse strain JF1, obtained from the National Institute for Genetics (Mishima, Shizuoka, Japan). All procedures undertaken in this study were approved by our institute's Animal Care and Use Committee and conform to Japanese guidelines.

\section{RT-PCR}

Total RNA was prepared from P21 B6 mouse cerebellum using Trizol reagent (Invitrogen) and reverse-transcribed by Superscript III reverse transcriptase (Invitrogen), using random primers, according to the manufacturer's protocol. The PCR of each $P c d h-\beta$ isoform was performed using cDNA as the template, $2 \mu \mathrm{l}$ of $10 \times$ Ex-taq PCR buffer, $2 \mu \mathrm{l}$ of $2.5 \mathrm{mM}$ each dNTP mix, $0.4 \mu$ l of RT-PCR primer set, $0.1 \mu$ l of Ex-taq HS polymerase (Takara, Japan), and water to a final volume of $20 \mu \mathrm{l}$. The PCR conditions were $3 \mathrm{~min}$ at $94^{\circ} \mathrm{C}$ and then 35 cycles of $30 \mathrm{~s}$ at $94^{\circ} \mathrm{C}$, $30 \mathrm{~s}$ at $60^{\circ} \mathrm{C}$ (for $P c d h-\beta 1$ ) or $58^{\circ} \mathrm{C}$ (for other $P c d h-\beta$ genes), and $2 \mathrm{~min}$ at $72^{\circ} \mathrm{C}$. The primer sets and sequences are shown in Table S1.

\section{In situ HYBRIDIZATION}

In situ hybridization was performed as described previously (Esumi et al., 2005; Kaneko et al., 2006; Watakabe et al., 2007; Katori et al., 2009; Noguchi et al., 2009; Watakabe et al., 2010; Yokota et al., 2011) on 10- $\mu$ m-thick frozen sagittal and coronal sections prepared from the B6 mouse using $P c d h-\beta$ highly conserved and isoform-specific cRNA probes. The mouse ages and regions examined are indicated in the figure legends. A probe for a highly conserved region of the $P c d h-\beta 2-\beta 22$ genes, pan- $P c d h-\beta$ probe, was designed based on the sequence in mouse $\beta 12$ (nucleotides 1422-2152 according to GeneBank ${ }^{\mathrm{TM}}$ accession number NM_053137). The $P c d h-\beta$ isoform-specific probes were designed based on mouse $\beta 3$ (nucleotides 237-1364; GeneBank ${ }^{\mathrm{TM}}$ accession number NM_053128), $\beta 15$ (nucleotides 161-1362; GeneBank ${ }^{\mathrm{TM}}$ accession number NM_053140), $\beta 16$ (nucleotides 277-1293; GeneBank $^{\mathrm{TM}}$ accession number NM_053141), $\beta 19$ (nucleotides 227-1147; GeneBank ${ }^{\mathrm{TM}}$ accession number NM_053144), and $\beta 22$ (nucleotides 213-1146; GeneBank ${ }^{\mathrm{TM}}$ accession number NM_053147). The similarity of each $P c d h-\beta$ isoform-specific 
probe to other $P c d h-\alpha, P c d h-\beta$, and $P c d h-\gamma$ genes and to other mouse genes was low enough (less than 65\%) to detect specific $P c d h-\beta$ transcripts of interest. These specific isoform sequences were amplified using the primers shown in Supplemental Table S1 (for in situ hybridization probe) and KOD-plus polymerase (Toyobo, Japan). The PCR product was cloned into the pCRII vector (Invitrogen), and the sequence was confirmed by DNA sequencing. The resultant plasmids were used as templates to synthesize digoxigenin (DIG)-11-UTP-labeled (Roche) cRNA probes.

To obtain tissue samples, mice were deeply anesthetized with diethyl ether, then the brain was removed, embedded in O.C.T. compound (Sakura), and quickly frozen in isopentane cooled with dry ice. Sections (10- $\mu \mathrm{m}$ thick) were cut on a cryostat (Leica CM3050), thaw-mounted on slides (Matsunami), and air-dried. The sections were fixed in $4 \%$ paraformaldehyde (PFA) in $0.1 \mathrm{M}$ phosphate buffer ( $\mathrm{PB}, \mathrm{pH} 7.3$ ) for $10 \mathrm{~min}$, washed three times in PBS, pH 7.4, acetylated for $10 \mathrm{~min}$ in $0.25 \%$ acetic anhydride in $0.1 \mathrm{M}$ triethanolamine- $\mathrm{HCl}, \mathrm{pH} 8.0$, and washed three more times with PBS. Prehybridization was performed with hybridization buffer $[50 \%$ formamide, $5 \times \mathrm{SSC}(20 \times \mathrm{SSC}$ is $3 \mathrm{M} \mathrm{NaCl}$, $0.3 \mathrm{M}$ sodium citrate, $\mathrm{pH} 7.0$ ), $5 \times$ Denhardt's, $250 \mu \mathrm{g} / \mathrm{ml}$ yeast tRNA, $500 \mu \mathrm{g} / \mathrm{ml}$ salmon sperm DNA, and $0.2 \%$ RNasin RNase inhibitor (Promega)] for $30 \mathrm{~min}$. The DIG-labeled cRNA probes were denatured for $5 \mathrm{~min}$ at $82^{\circ} \mathrm{C}$ and chilled on ice. The sections were covered with hybridization buffer containing $1 \mu \mathrm{g} / \mathrm{ml}$ of the cRNA probes, added drop wise, and a coverslip was added. The slides were incubated for $12 \mathrm{hrs}$ at $72^{\circ} \mathrm{C}$ in a humidified chamber (50\% formaldehyde, $5 \times$ SSC), washed three times with $0.2 \times$ SSC at $72^{\circ} \mathrm{C}$, washed three times with TBS, pH $7.5(100 \mathrm{mM}$ Tris- $\mathrm{HCl}$, $\mathrm{pH} 7.5,100 \mathrm{mM} \mathrm{NaCl})$, and rinsed with TNT (0.05\% Tween 20 in TBS, pH 7.5). To detect the hybridized probes, the sections were blocked with $1 \times$ blocking solution (Roche) in TNT for $30 \mathrm{~min}$, and then incubated with alkaline phosphatase (AP)-conjugated anti-DIG antibody (1:1000 dilution, Roche) in the blocking solution for $1 \mathrm{~h}$. The sections were rinsed three times with TBS, $\mathrm{pH} 7.5$, and the enzymatic activity was visualized with $0.2 \mathrm{mM}$ 5-bromo-4-chloro-3-indolyl-phosphate, $0.2 \mathrm{mM}$ nitro blue tetrazolium (NBT/BCIP) in $100 \mathrm{mM}$ Tris- $\mathrm{HCl}, \mathrm{pH} 9.5,100 \mathrm{mM} \mathrm{NaCl}$, $20 \mathrm{mM} \mathrm{MgCl}_{2}$, in the dark, until the signal reached a satisfactory intensity.

We also carried out double fluorescence in situ hybridization. Fluorescein (FITC)-labeled cRNA probes against glutamate decarboxylase 1 (GAD67), choline O-acetyltransferase (ChAT), and vesicular acetylcholine transporter $(V A C h T)$ were synthesized with a FITC-UTP RNA labeling Kit (Roche). The probes were designed based on mouse GAD67 (nucleotides $1073 \sim 2012$; GeneBank ${ }^{\mathrm{TM}}$ accession number NM_008077), rat ChAT (nucleotides 243 $\sim$ 745; GeneBank ${ }^{\mathrm{TM}}$ accession number NM_001170593), and rat VAChT (Slc18a3) (nucleotides $1201 \sim 2194$; GeneBank ${ }^{\mathrm{TM}}$ accession number NM_031663). The DIG-labeled $P c d h-\beta$ probe and a FITC-labeled GAD67, ChAT, or VAChT cRNA probe were hybridized to sections, which were washed as above.

To detect the FITC-labeled probes, the sections were incubated with an anti-FITC antibody conjugated with horseradish peroxidase (Jackson Immuno Research Laboratory, 1:4000 in the blocking buffer) for $2-5 \mathrm{hrs}$ at room temperature. After being washed in TNT three times for $15 \mathrm{~min}$, the sections were treated with 1:50 diluted TSA-Plus [dinitrophenol (DNP)] reagents for $5 \mathrm{~min}$, according to the manufacturer's instructions (PerkinElmer, Wellesley, MA), which converted the FITC signals to DNP signals. After being washed in TNT three times for $10 \mathrm{~min}$, the sections were incubated overnight at $4^{\circ} \mathrm{C}$ with an anti-DNP antibody conjugated with Alexa488 (1/500, Molecular Probes) in $1 \%$ blocking buffer. At this point, an anti-DIG antibody conjugated with AP (1:1000, Roche Diagnostics) was included in the incubation, to detect the DIG-labeled probes. The AP activity was visualized with NBT/BCIP (see above) or with HNPP fluorescence.

To detect the DIG-labeled probes with HNPP fluorescence, the sections were washed three times in TNT, once in TS 8.0 (0.1 M Tris- $\mathrm{HCl}, \mathrm{pH} 8.0,0.1 \mathrm{M} \mathrm{NaCl}, 50 \mathrm{mM} \mathrm{MgCl}_{2}$ ), and the AP activity was detected using an HNPP fluorescence detection set (Roche Diagnostics), according to the manufacturer's instructions. The incubation for this substrate was carried out for $30 \mathrm{~min}$ and stopped by washing in TS 8.0. The sections were then counterstained with 4',6-diamidino-2-phenylindope, dihydrochloride (DAPI, Invitrogen, USA) diluted in TS $8.0-100 \mathrm{ng} / \mathrm{ml}$ for $3 \mathrm{~min}$. After a brief wash in TS 8.0, the sections were mounted with CC/Mount (Diagnostic Biosystems, Pleasanton, CA) mounting medium.

\section{SPLIT SINGLE-CELL $3^{\prime}$-RACE OF PURKINJE CELLS}

A split single-cell $3^{\prime}$-RACE method for single Purkinje cells was developed to analyze the one-exon $P c d h-\beta 3, \beta 9, \beta 10, \beta 15, \beta 19$, and $\beta 22$ genes, and was based on our previously published method for single-cell RT-PCR (Esumi et al., 2006). The primer sets and sequences are shown in Table $\mathbf{S 1}$ (for split single-cell 3 '-RACE). In brief, Purkinje cells were prepared from the cerebellum of P21 mice, from the F1 litter of a B6 female $\times$ JF1 male. The tissue was dissected and digested with 90 units of papain (Worthington) at $37^{\circ} \mathrm{C}$ for $30 \mathrm{~min}$ in $10 \mathrm{ml}$ of dissociation solution $[0.002 \%$ DL-cysteine $\mathrm{HCl}$ (Sigma), 0.05\% DNase I (Sigma), 0.1\% bovine serum albumin (Sigma), and 0.05\% glucose (Nacalai Tesque)]. The digested tissue was spun for $8 \mathrm{~min}$ at $300 \times \mathrm{g}$, and the pellet was resuspended in Dulbecco's modified Eagle's medium (Sigma). To remove debris, the cells were filtered through a $100-\mu \mathrm{m}$ cell strainer (Falcon). Single Purkinje cells were picked up by glass capillary and placed in thin, 200$\mu \mathrm{l}$ PCR tubes, with $6 \mu \mathrm{l}$ of RNase-free water. Complementary DNA was synthesized from the single-cell samples after adding $12.5 \mathrm{pmol} /$ reaction of adaptor-attached oligo dT primer and 2.5 $\mathrm{pmol} /$ reaction of $P c p-2$ RT primer in a total volume of $10 \mu \mathrm{l}$, using six units of Thermoscript reverse transcriptase (Invitrogen), according to the manufacturer's protocol, at $55^{\circ} \mathrm{C}$ for $60 \mathrm{~min}$. The reaction was stopped by heating at $85^{\circ} \mathrm{C}$ for $5 \mathrm{~min}$.

The cDNAs derived from a single Purkinje cell were split into three PCR tubes as 3.3- $\mu \mathrm{l}$ aliquots and used as a template for the first round of a multiplex PCR, which was performed using the $3.3 \mu \mathrm{l}$ of cDNA, $2.5 \mu \mathrm{l}$ of $10 \times$ Ex-taq PCR buffer, $2 \mu \mathrm{l}$ of $2.5 \mathrm{mM}$ each dNTP mix, $1.5 \mu$ l of the first PCR primer set, $0.1 \mu$ l of Ex-taq HS polymerase (Takara), and $15.6 \mu \mathrm{l}$ of water. The PCR conditions were an initial $3 \mathrm{~min}$ at $95^{\circ} \mathrm{C}$ and then 28 cycles of $20 \mathrm{~s}$ at $95^{\circ} \mathrm{C}, 20 \mathrm{~s}$ at $58^{\circ} \mathrm{C}$, and $5 \mathrm{~min}$ at $68^{\circ} \mathrm{C}$. The first PCR products 
were split into $0.5-\mu 1$ aliquots, which were used as the template in the second round of nested PCR with $2 \mu \mathrm{l}$ of $10 \times$ Ex-taq PCR buffer, $1.6 \mu$ l of $2.5 \mathrm{mM}$ each dNTP mix, $0.4 \mu \mathrm{l}$ of the second PCR primer set, $0.1 \mu \mathrm{l}$ of Ex-taq HS polymerase (Takara), and $15.4 \mu \mathrm{l}$ of water. The PCR conditions for the $P c d h-\beta$ genes were an initial $3 \mathrm{~min}$ at $96^{\circ} \mathrm{C}, 40 \mathrm{cycles}$ of $30 \mathrm{~s}$ at $96^{\circ} \mathrm{C}, 15 \mathrm{~s}$ at $56^{\circ} \mathrm{C}$ (for $\beta 3, \beta 9$, and $\beta 15$ ) or $58^{\circ} \mathrm{C}$ (for $\beta 10, \beta 19$, and $\beta 22$ ), and $1 \mathrm{~min}$ at $72^{\circ} \mathrm{C}$. The PCR conditions for the $\beta$-actin and Pcp- 2 were described in previous reports (Esumi et al., 2005, 2006; Kaneko et al., 2006). The primer sets and sequences are shown in Table S1.

The secondary PCR products were divided into two tubes. One PCR-amplified product was analyzed by agarose gel electrophoresis: before loading, the sample was mixed with electrophoresis loading buffer (Takara) and heated to $72^{\circ} \mathrm{C}$ for $5 \mathrm{~min}$, to sharpen the electrophoretic bands. The other half of the PCR sample was purified by polyethylene glycol precipitation and sequenced by direct sequencing, using a BigDye ${ }^{\mathrm{TM}}$ DNA sequencing kit (version 3.1) (ABI). The data were analyzed on an ABI Prism 3100 or an ABI Prism 3730 Genetic Analyzer. Direct sequencing permitted us to identify the allele from which each purified PCR product was derived. The discrimination of monoallelic expression from biallelic expression was accomplished using SeqScape software (ABI). The sequencing results from each 3 '-RACE PCR product were confirmed by performing direct sequencing twice, using two distinct pairs of forward and reverse primers.

\section{RESULTS}

\section{EXPRESSION OF THE Pcdh- $\boldsymbol{\beta}$ TRANSCRIPTS IN MOUSE BRAIN}

To examine the expression pattern of each $P c d h-\beta$ gene in the brain, we first carried out an RT-PCR analysis of all 22 Pcdh$\beta$ gene family exons, using cDNA from the P21 mouse cerebellum (Figure 1A). This analysis clearly showed that all 22 $P c d h-\beta$ gene family exons were transcribed in the cerebellum. Next, we identified the $3^{\prime}$ ends of some of the $P c d h-\beta$ transcripts by $3^{\prime}$-RACE analysis using RNA from P21 mouse cerebellum (Table S2). No spliced product of $P c d h-\beta$ with constant region exons of $P c d h-\alpha$ or $P c d h-\gamma$ was detected by first-round RT-PCR analysis (data not shown). These data re-confirmed that the $P c d h-\beta$ genes are transcribed as $3^{\prime}$ polyadenylated mRNAs (Vanhalst et al., 2001).

The distribution of the $P c d h-\beta$ transcripts in the P21 mouse brain was examined by in situ hybridization (Figures 1B,C). Because the DNA sequence that corresponds to extracellular cadherin domain 4 (EC4)-EC5-EC6 of $P c d h$ - $\beta 12$ is highly conserved from $\beta 2$ to $\beta 22$ (more than $84 \%$ similarity), we used this sequence as a pan- $P c d h-\beta$ probe $(P c d h-\beta$ highly conserved probe, hereafter) to detect all 21 isoforms of $P c d h-\beta$. We excluded the $\beta 1$ gene from this study because of its low similarity to $\beta 2-\beta 22$. The $P c d h-\beta$ highly conserved probe hybridized widely in the brain, and prominent signals were observed in the olfactory bulb, hippocampus, and cerebellum. No signal was observed with the sense probe (data not shown). These results are consistent with findings obtained for rat brain (Sago et al., 1995).

To examine the distribution of each member of the $P c d h-\beta$ subfamily genes, we performed an in situ hybridization analysis using probes that detected specific $P c d h-\beta$ isoforms. Sequences showing low similarity $(<65 \%)$ with other $P c d h-\beta$ gene members

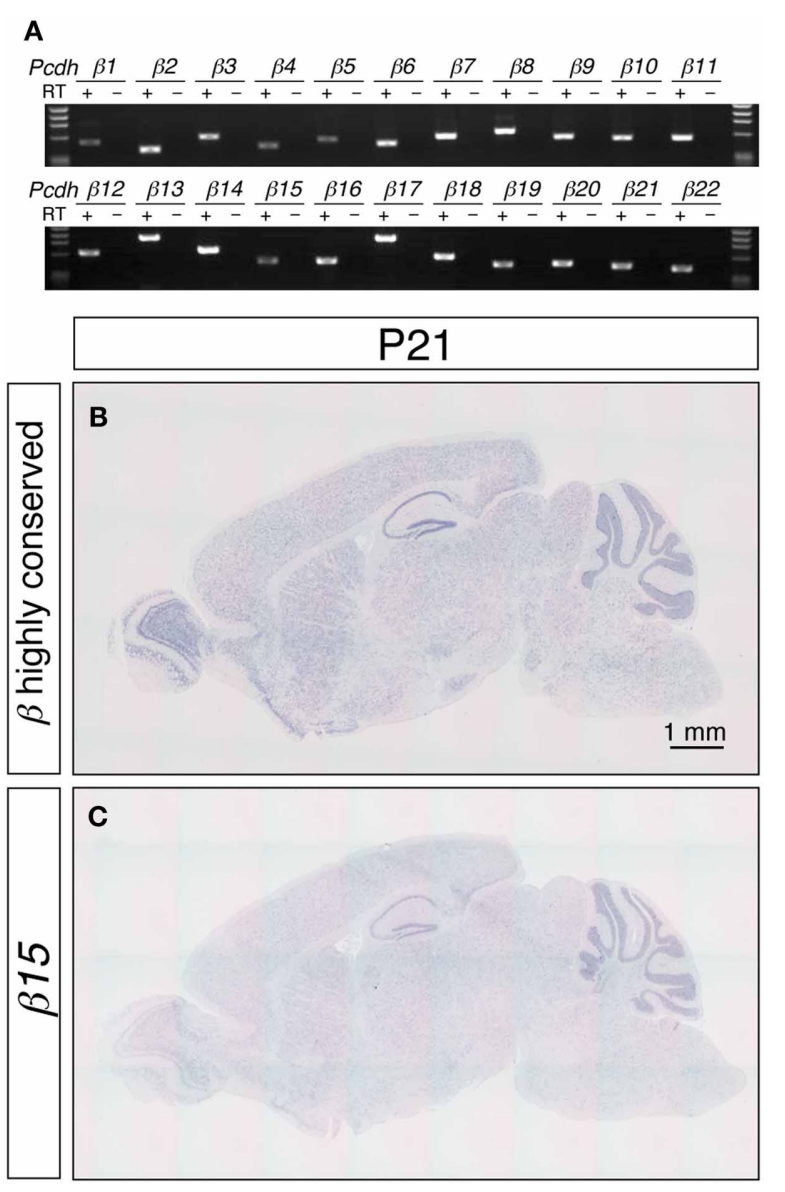

FIGURE 1 | Expression of the Pcdh- $\beta$ transcripts in the mouse brain. (A) RT-PCR analysis of P21 cerebellum using isoform-specific primers demonstrated that all 22 of the $P c d h-\beta$ transcripts were expressed. In situ hybridization analysis with a $P c d h-\beta$ highly conserved probe (B) and with a probe specific for $\beta 15$ (C). Sagittal sections of P21 mouse brain are shown. The distributions of the signals were almost identical, but the intensity of the $\beta 15$-specific probe at the macroscopic level was weaker than that obtained with the Pcdh- $\beta$ highly conserved probe, suggesting that the expression of the Pcdh- $\beta$ transcripts overlapped at the macroscopic level.

were used as probes. Although the $P c d h-\beta$ genes are very similar to each other, the similarity of $\beta 3, \beta 15, \beta 16, \beta 19$, and $\beta 22$ is relatively low, and could be reliably discriminated. When examined at low magnification, the signals for $\beta 15$ (Figure 1C) and the other 4 Pcdh- $\beta$ genes (data not shown) hybridized in a pattern that was identical to that obtained using the $P c d h-\beta$ highly conserved probe, but with lower signal intensity. These results suggested that the $P c d h-\beta$ isoforms, at least $\beta 3, \beta 15, \beta 16, \beta 19$, and $\beta 22$, have macroscopically overlapping expression patterns in the mouse brain.

\section{MONOALLELIC AND COMBINATORIAL GENE REGULATION OF $P c d h-\beta$ GENES IN SINGLE PURKINJE CELLS}

To investigate the gene regulation of the $P c d h-\beta$ cluster, we examined the expression patterns of the $P c d h-\beta$ transcripts in cerebellar Purkinje cells, since the regulation of the $P c d h-\alpha$, and $P c d h-\gamma$ clusters was extensively studied in these cells (Esumi 
et al., 2005; Kaneko et al., 2006). In the P21 cerebellum, the $P c d h-\beta$ highly conserved probe intensely stained most Purkinje cells (Figure 2A). In contrast, the specific probes for $\beta 3, \beta 15$, $\beta 16, \beta 19$, and $\beta 22$ stained only a subset of the Purkinje cells (Figures 2B-F), showing that the $P c d h-\beta$ isoforms, at least $\beta 3$, $\beta 15, \beta 16, \beta 19$, and $\beta 22$, were expressed in a scattered pattern among the Purkinje cells. Next, we analyzed the age-dependence of the expression patterns of the $P c d h-\beta$ genes in Purkinje cells. From P10 to P150, all the Purkinje cells were intensely stained by the $P c d h-\beta$ highly conserved probe (Figures $2 A, \mathbf{G}, \mathbf{I}, \mathbf{K}, \mathbf{M}$ ), whereas the specific probe for $\beta 15$ stained only a subset of Purkinje cells (Figures 2C,H,J,L,N). Likewise, the specific probes for $\beta 3, \beta 16, \beta 19$, and $\beta 22$ stained only subsets of the Purkinje cells, resulting in scattered patterns such as those seen at P21 (data not shown). Therefore, the expression of the $\beta 3, \beta 15, \beta 16$, $\beta 19$, and $\beta 22$ isoforms, and probably all of the $P c d h-\beta$ isoforms, was scattered among Purkinje cells from P10 to P150. On the other hand, in granule cells stained signals for both $P c d h-\beta$ highly conserved and specific $\beta 15$ probes were reduced in P90 and P150.
The next step was to confirm the differential expression revealed by the in situ hybridization, and to further investigate whether the gene regulation of $P c d h-\beta$ transcripts in single neurons is monoallelic and combinatorial. For this purpose, we modified our split single-cell RT-PCR method. Since the $P c d h-\beta$ genes consist of only one exon (Vanhalst et al., 2001), conventional RT-PCR against $P c d h-\beta$ exon could amplify not only the $P c d h$ $\beta$ transcripts but also the genomic DNA, leading us to erroneous conclusions. Fortunately, the $P c d h-\beta$ transcripts are polyadenylated (Table S2), so we adapted our method to $3^{\prime}$-RACE. First, we searched for a region of strong similarity shared by several of the $P c d h-\beta$ genes to use in the first multiplex primer annealing and found that base pairs 2289-2307 of $\beta 15$ are highly conserved in $\beta 3, \beta 9, \beta 10, \beta 15, \beta 19$, and $\beta 22$. We next sequenced the region proximal to the functional polyadenylation signal of these six $P c d h-\beta$ genes in the JF1 mouse strain, and detected polymorphisms against the B6 strain (Figure S1). These data ultimately led us to choose $\beta 3, \beta 9, \beta 10, \beta 15, \beta 19$, and $\beta 22$ as the targets for this analysis.

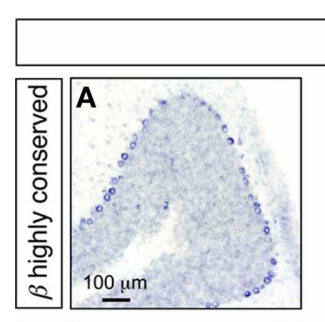

Cerebellum, P21
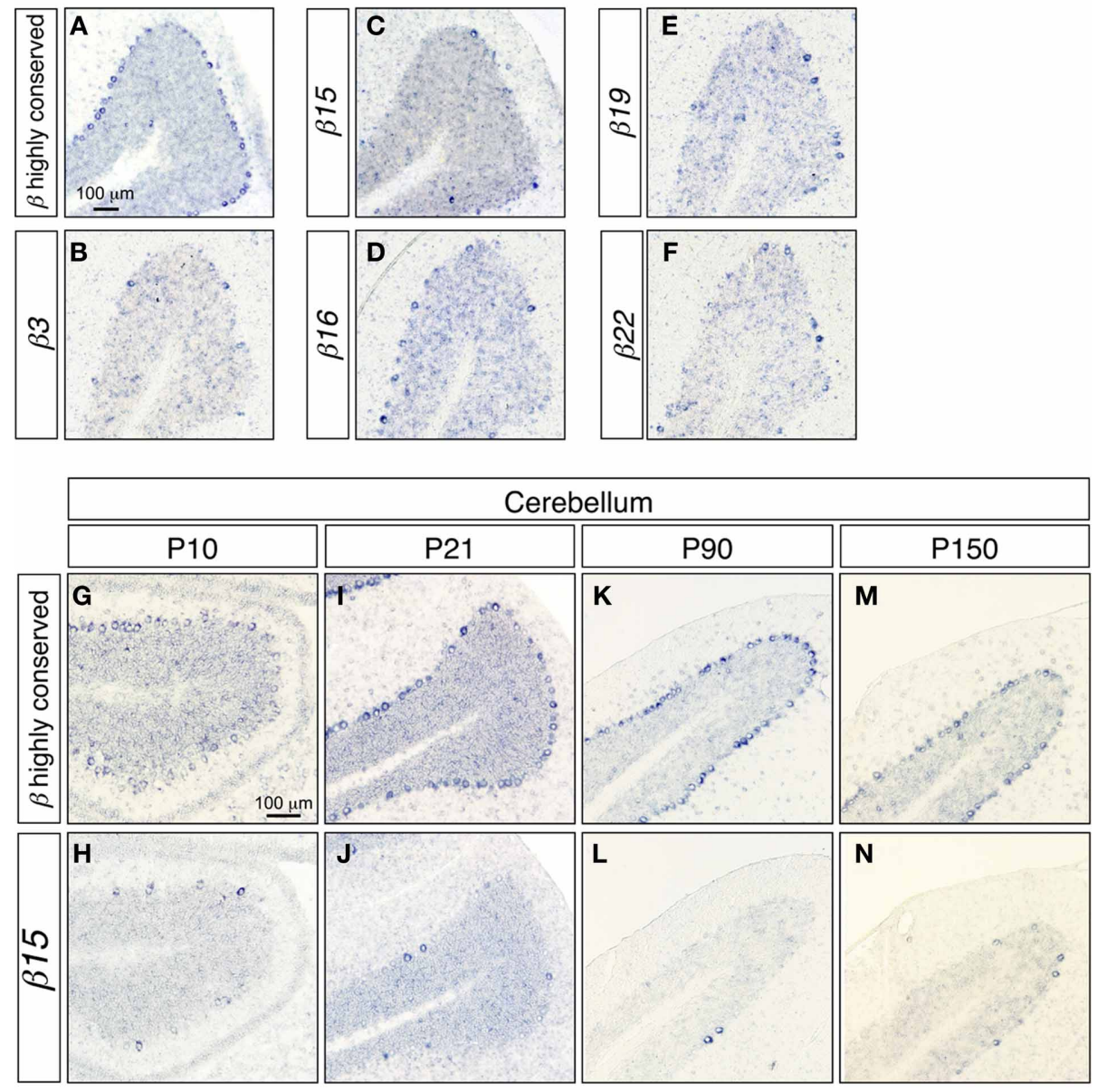

FIGURE 2 | In situ hybridization analysis of $P \boldsymbol{c d h}-\boldsymbol{\beta}$ in the mouse cerebellum. (A-F) Coronal sections. (A) In situ hybridization with the Pcdh- $\beta$ highly conserved probe; (B-F) in situ hybridization using probes specific for $\beta 3$ (B), $\beta 15$ (C), $\beta 16$ (D), $\beta 19$ (E), and $\beta 22$ (F). (G-M) Comparison of staining with the Pcdh- $\beta$ highly conserved probe $(\mathbf{G}, \mathbf{I}, \mathbf{K}, \mathbf{M})$ and the $\beta 15$-specific probe (H,J,L,N) at P10-P150. 
We tested our split single-cell 3'-RACE method using Purkinje cells of P21 F1 mice from a B6 $\times$ JF1 cross. After optimizing the experimental conditions, we reproducibly obtained the predicted fragments for $\beta 3, \beta 9, \beta 10, \beta 15, \beta 19, \beta 22, \beta$-actin (positive control for $3^{\prime}$-RACE amplification), and $P c p-2$ (a marker for Purkinje cells). Only single Purkinje cell-derived cDNA samples that showed intense expressions of $P c p-2$ and $\beta$-actin were used for the expression analysis of the individual $P c d h-\beta$ isoforms in subsequent experiments.

Next, we analyzed the expression patterns of the $\beta 3, \beta 9, \beta 10$, $\beta 15, \beta 19$, and $\beta 22$ transcripts in single Purkinje cells using the split single-cell $3^{\prime}$-RACE method (Figure 3). Of the 28 single Purkinje cells analyzed, all were positive for the PCR products of $P c p-2$ and $\beta$-actin, confirming that they were mature Purkinje cells, and their mRNAs were successfully reverse-transcribed. None of the control samples (\#1-8, \#1-16, \#1-24, \#1-32, or \#1-40), which did not contain Purkinje cells, yielded PCR products, confirming the reliability of this method.

When the cells were subjected to the $P c d h-\beta$ gene-specific second-round PCR, 21 cells were positive for some of the Pcdh- $\beta$ genes. Of these, 15 showed specific amplification of one of the six $P c d h-\beta$ genes investigated in all three (3/3) sample tubes (for example, $\beta 10$ in Cell \#1-1, $\beta 15$ in Cell \#1-2, and $\beta 19$ in Cell \#1-5). In addition to the $3 / 3$ PCR amplifications, five Purkinje cells showed specific PCR amplifications in $2 / 3$ tubes (for example, $\beta 19$ in Cells \#1-3, $\beta 3$ in Cell \#1-15, and $\beta 22$ in Cell \#1-18), and specific PCR amplification was seen in $1 / 3$ tubes for two Purkinje cells ( $\beta 22$ in Cell $\# 1-13$ and $\beta 9$ in Cell \#138 ). Obtaining only $2 / 3$ and $1 / 3$ positive tubes may suggest that these cells contained a low amount of the corresponding mRNAs. The remaining seven cells were negative for any of the $P c d h-\beta$ genes, probably indicating that other $P c d h-\beta$ genes not included in this analysis were expressed by these cells. Finally, more than one $P c d h-\beta$ isoform was amplified in $3 / 3$ tubes of three Purkinje cells ( $\beta 9$ and $\beta 19$ in Cell $\# 1-10, \beta 3$ and $\beta 22$ in Cell $\# 1-12$, and $\beta 9$ and $\beta 19$ in Cell \#1-17). These results strongly suggested that the $P c d h-\beta$ genes are expressed in Purkinje cells in a differential and combinatorial manner.

Next, each PCR product was directly sequenced to distinguish among three possible patterns of expression: monoallelic expression of the maternal allele, monoallelic expression of the paternal allele, and biallelic expression. In the case of $\beta$-actin, all the PCR products showed a biallelic expression pattern. This was consistent with our previous analysis (Esumi et al., 2005; Kaneko et al., 2006), which was obtained by split single-cell RT-PCR. Thus, these findings confirmed the reliability of the present method. In contrast to $\beta$-actin, a monoallelic expression pattern was found for the $P c d h-\beta$ genes in 17 of the $183 / 33^{\prime}$-RACE-positive products (94\%) (Figure 4) as follows: $\beta 10$ in Cell $\# 1-1, \beta 15$ in Cell $\# 1-2, \beta 19$ in Cell \#1-5, $\beta 9$ in Cell \#1-7, $\beta 19$ in Cell \#1-5, $\beta 9$ and
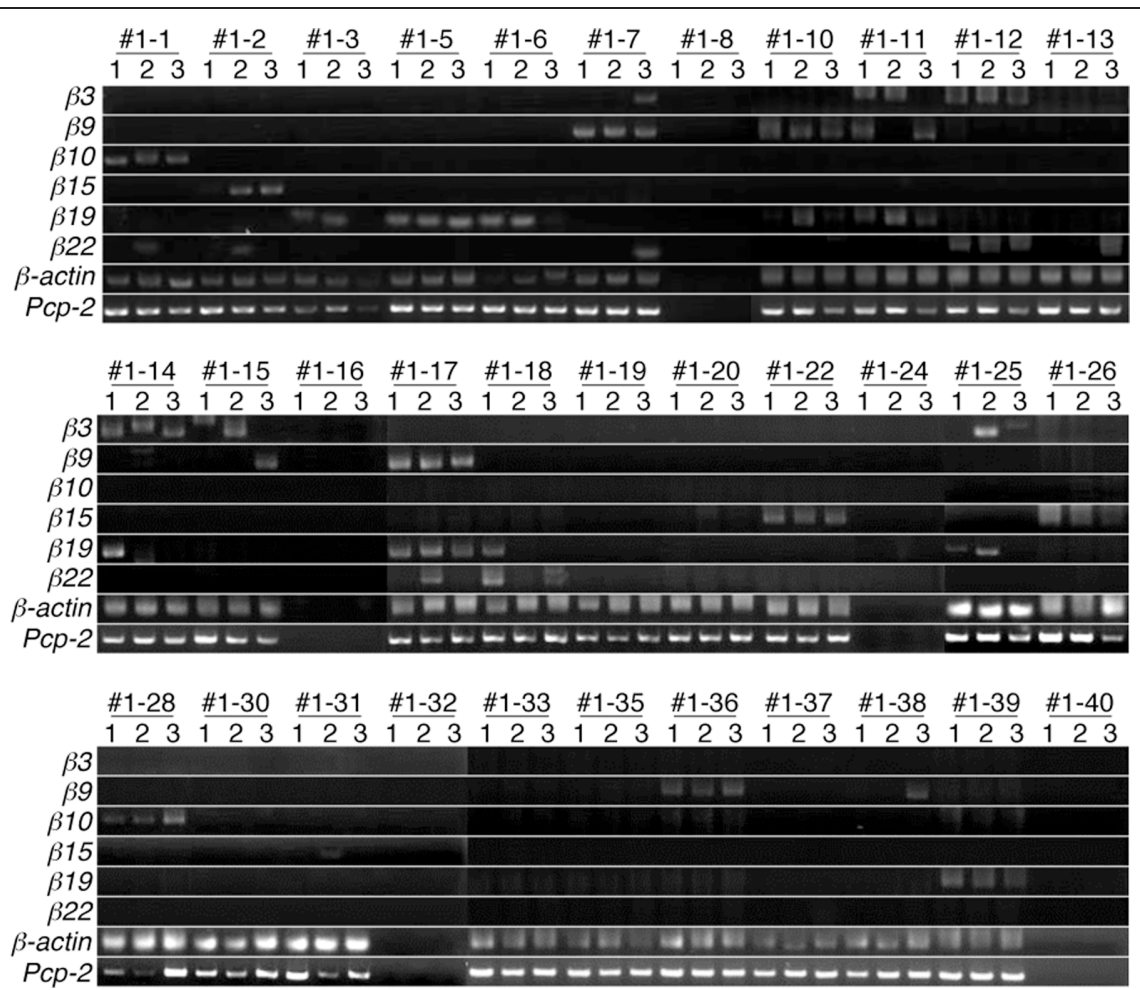

FIGURE 3 | Split single-cell $\mathbf{3}^{\prime}$-RACE analysis of $\boldsymbol{P} \boldsymbol{c} \boldsymbol{c} \boldsymbol{h} \boldsymbol{h} \boldsymbol{\beta} \boldsymbol{\beta}$ in Purkinje cells. Purkinje cells were from the P21 F1 progeny of a cross between the B6 and JF1 strains. Individual Purkinje cells are indicated as \#1-1 to \#1-39. Samples \#1-8, \#1-16, \#1-24, \#1-32, and \#1-40 were negative controls that contained no cells. The RNAs in each Purkinje cell were reverse transcribed using an adapter-attached oligo dT primer and a PCp-2-specific primer set. Each RT sample was divided into three separate tubes and subjected to $3^{\prime}$-RACE (PCR). The three independent PCR products are referred to as 1,2 , and 3 . The results for electrophoresis of the second-round $3^{\prime}$-RACE (PCR)-products are shown. 


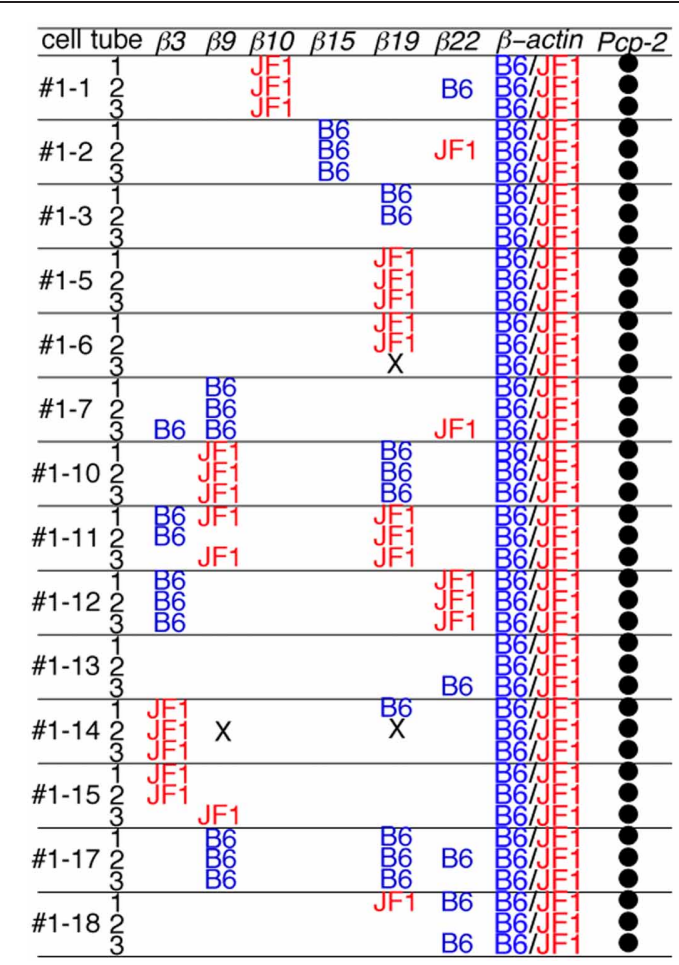

FIGURE 4 | Distribution of the B6 and JF1 alleles as the source of each $\boldsymbol{P c d h} \boldsymbol{\beta} \boldsymbol{\beta}$ gene in individual Purkinje cells. To determine whether the amplified 3'-RACE (PCR) products were from the B6 or JF1 allele, we performed direct sequencing of the products in each of the three

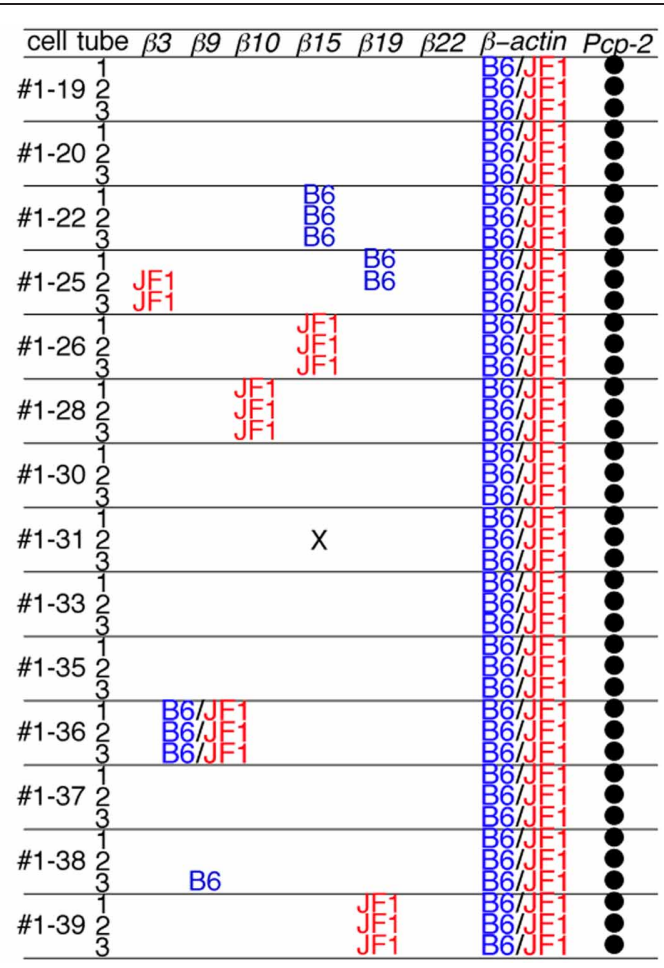

tubes from 28 Purkinje cells. The samples that contained an insufficient quantity of product for sequencing are indicated with an $\mathrm{X}$. The amplified $P c p-2$ products were not sequenced and are indicated with a closed circle. $\beta 19$ in Cell \#1-10, $\beta 19$ in Cell \#1-11, $\beta 3$ and $\beta 22$ in Cell \#1-12, $\beta 3$ in Cell \#1-14, $\beta 9$ and $\beta 19$ in Cell \#1-17, $\beta 15$ in Cell \#1-22, $\beta 15$ in Cell \#1-26, $\beta 10$ in Cell \#1-28, $\beta 19$ in Cell \#1-39. Biallelic expression was observed only for $\beta 9$ in Cell \#1-36. Statistically, if this assay amplified only a single cDNA molecule, even though biallelic products were present in the PCR tube, an artifactual 3/3 monoallelic expression pattern would theoretically be observed for $25 \%$ of the cells (Rhoades et al., 2000). Clearly, at $94 \%$ vs. $25 \%$, there was a highly significant difference, which was upheld by a $\chi$-square analysis between monoallelic and biallelic expression $\left(P<10^{-4}\right)$. Of the 17 monoallelically expressed genes, seven were derived from the $\mathrm{B} 6$ allele and 10 from the JF1 allele. Thus, no allelic distortion from the paternal or maternal allele was found in this assay. Taken together, these results clearly showed that the $P c d h-\beta$ cluster genes are regulated monoallelically and combinatorially in individual Purkinje cells. This gene regulation would provide the molecular basis for the random expression of the $P c d h-\beta$ cluster genes, similar to the $P c d h-\alpha$ and $P c d h-\gamma$ clusters.

\section{DIVERSITY OF THE $\mathbf{3}^{\prime}$-TERMINUS OF THE Pcdh- $\beta$ TRANSCRIPTS WITHIN SINGLE PURKINJE CELLS}

During the expressional analysis of the $P c d h-\beta$ transcripts using single-cell $3^{\prime}$-RACE, we simultaneously analyzed whether the $3^{\prime}$-terminus of each $P c d h-\beta$ transcript in single neurons was homogeneous or heterogeneous (Figure 5). In most individual
Purkinje cells, the $3^{\prime}$-terminus of each $P c d h-\beta$ transcript was homogeneous, although we observed $3^{\prime}$-terminal heterogeneity in two cells: $P c d h-\beta 22$ in Cell \#2-10 (Figures 5A,C) and $P c d h$ $\beta 15$ in Cell \#2-21 (Figures 5B,D). The $\beta 22$ transcripts in Cell $\# 2-10$ showed three types of $3^{\prime}$-termini, while the $\beta 15$ transcripts in Cell \#2-21 showed two types of $3^{\prime}$-termini. These data indicate that the polyadenylation of each $P c d h-\beta$ gene within a single neuron is not always homogeneous, suggesting the existence of transcriptional diversity for each Pcdh- $\beta$ gene.

\section{SCATTERED EXPRESSION OF Pcdh- $\beta$ TRANSCRIPTS IN THE CENTRAL AND PERIPHERAL NERVOUS SYSTEMS}

To extend our knowledge of the neuron types that showed random expression of the $P c d h-\beta$ cluster genes, which might correspond to the specification of individual neuron identity, we examined the expression of $P c d h-\beta$ genes in a wide range of neurons using in situ hybridization. In the P21 hippocampus, intense signals from the $P c d h-\beta$ highly conserved probe were observed in all the pyramidal cell-layer neurons in CA1 and CA3 (Figures 6A,D,G). In contrast, the specific probes for $\beta 15$ and $\beta 22$ stained only subsets of these neurons (Figures $\mathbf{6 B}, \mathbf{E}, \mathbf{H}$, and $\mathbf{C , F}, \mathbf{I}$, respectively). The other specific probes (for $\beta 3, \beta 16$, and $\beta 19$ ) also stained only subsets of these neurons (data not shown). Furthermore, in the P21 cerebral cortex, most neurons showed intense staining for the $P c d h-\beta$ highly conserved 


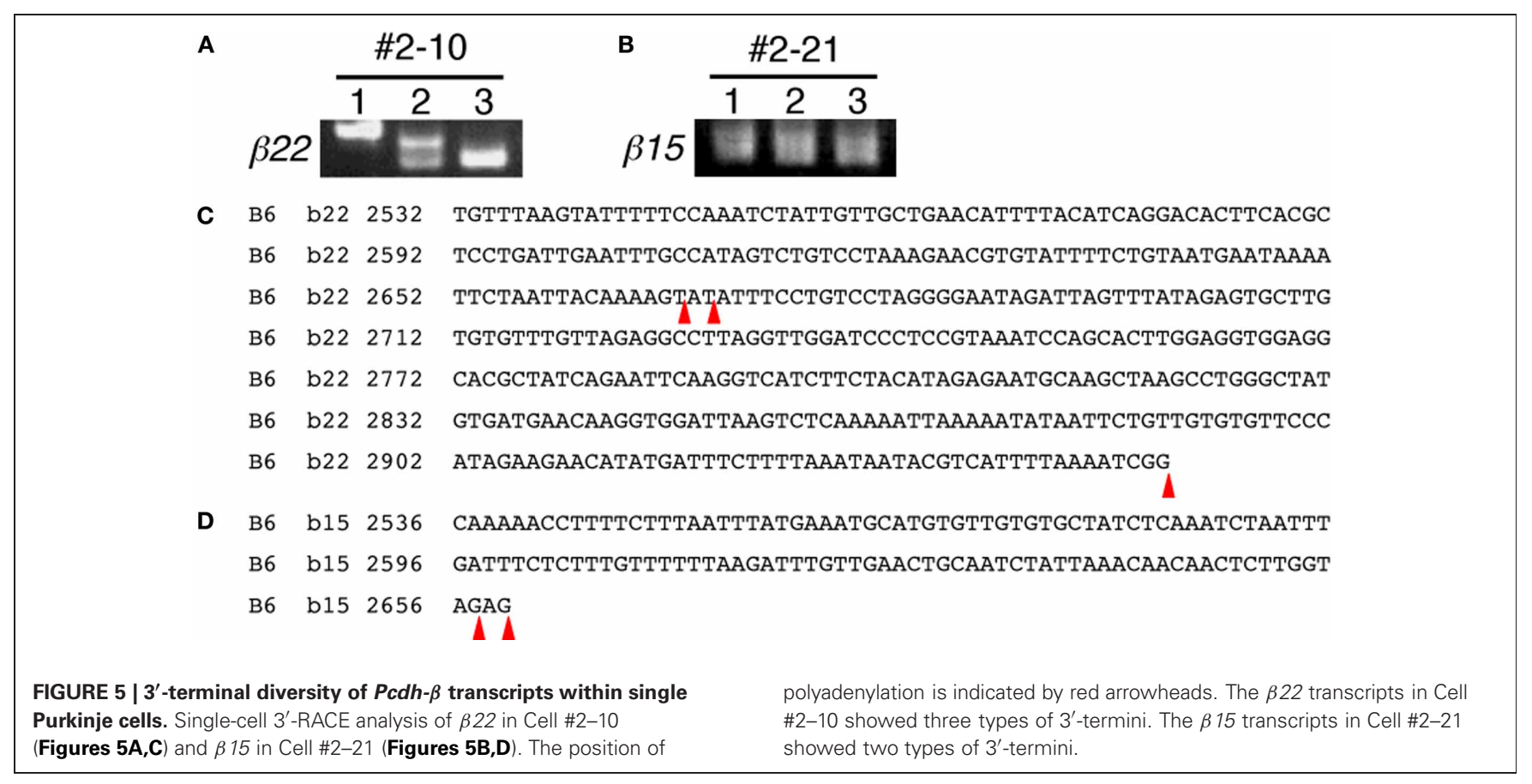

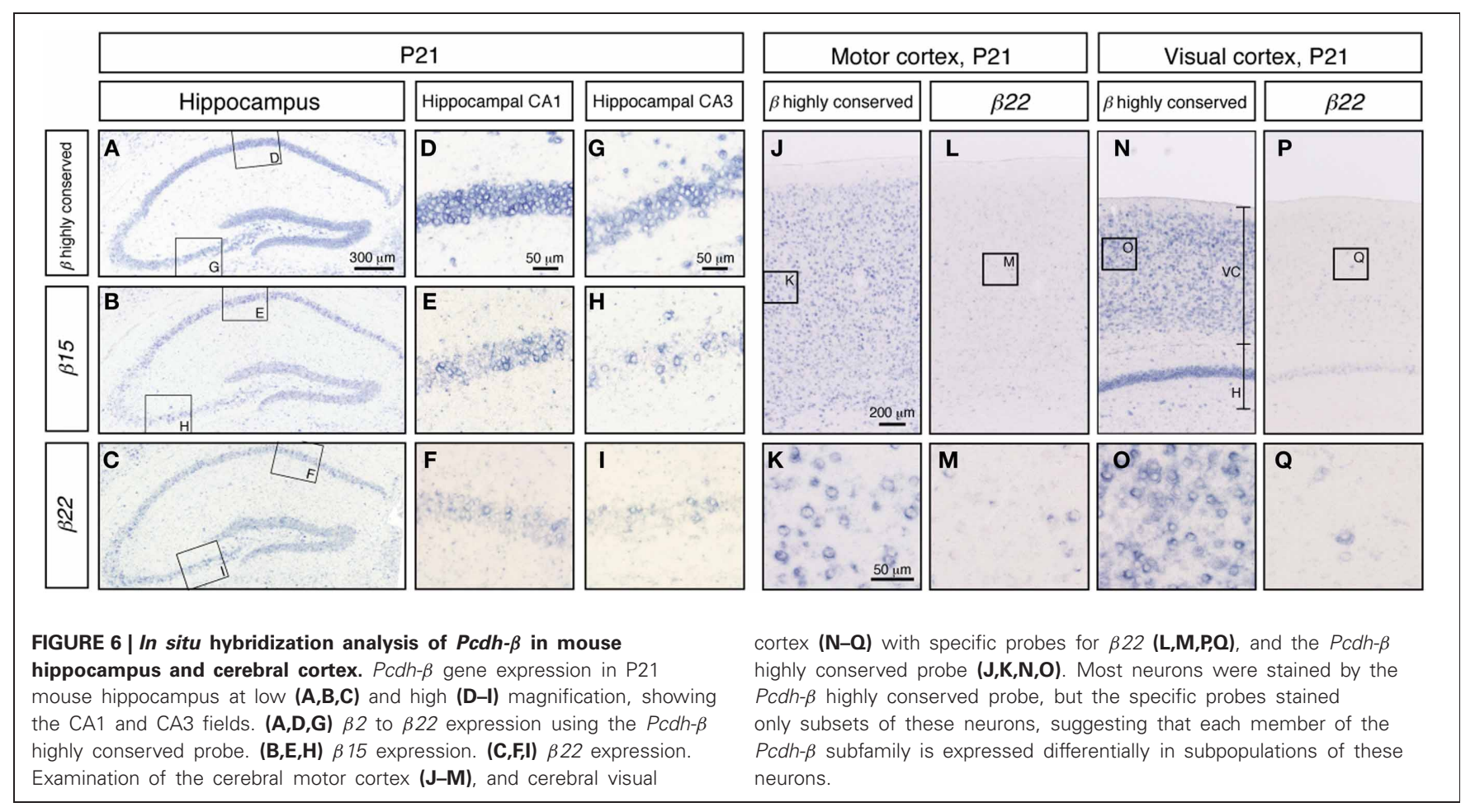

probe (see Figures 6J and $\mathbf{K}$ for staining in the P21 motor cortex and Figures $\mathbf{6 N}$ and $\mathbf{O}$ for staining in the P21 visual cortex). In contrast, the specific probe for $\beta 22$ stained only a subset of neurons in each of these regions (Figures 6L,M,P,Q), as did the other specific probes (data not shown). These results clearly demonstrated that these $P c d h-\beta$ gene isoforms were expressed only in subsets of neurons in the cerebral cortex and of pyramidal neurons in the hippocampal CA1 and CA3 areas, indicating that these $P c d h-\beta$ gene isoforms are expressed randomly and differentially in these neurons.

We also examined the expression of the $P c d h-\beta$ transcripts in the trigeminal and dorsal root ganglia. As in the cerebral cortex and the hippocampus, these peripheral nervous system neurons showed prominent signals from the $P c d h-\beta$ highly conserved 


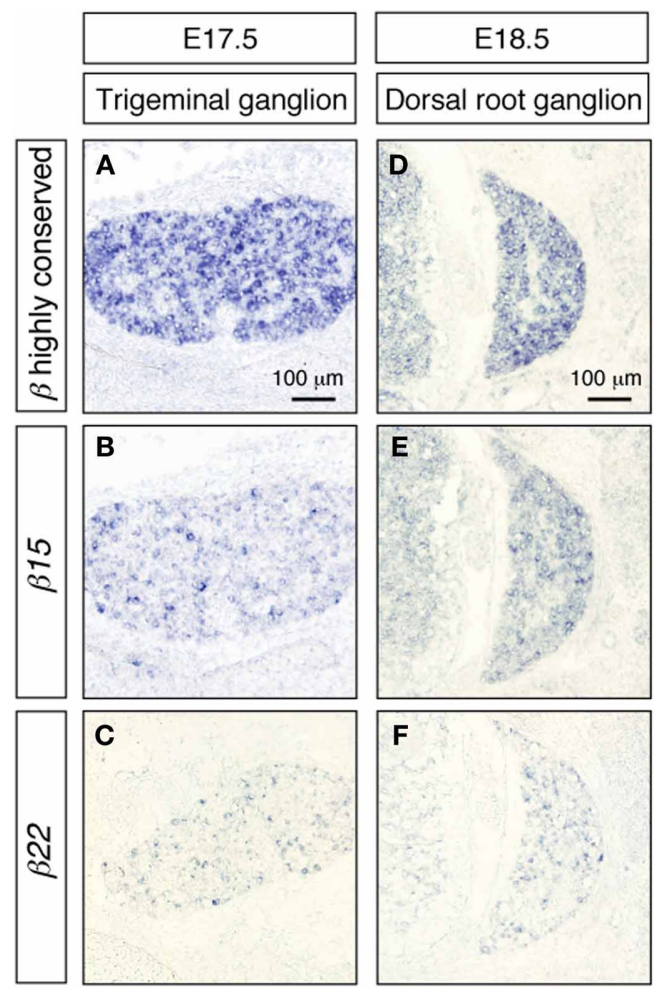

FIGURE 7 | In situ hybridization analysis of $\boldsymbol{P c d h}-\boldsymbol{\beta}$ genes in mouse trigeminal and dorsal root ganglia. $\beta 2$ to $\beta 22$ expression using the Pcdh- $\beta$ highly conserved probe on embryonic mouse trigeminal ganglion (A) and dorsal root ganglion (D). (B,E) Specific expression of $\beta 15 ;(\mathbf{C}, \mathbf{F})$ specific expression of $\beta 22$. Most neurons were stained by the $P c d h-\beta$ highly conserved probe, but the specific probes stained only subsets of these neurons, suggesting that each member of the $P c d h-\beta$ subfamily is expressed differentially in subpopulations of these neurons.

probe (Figures 7A,D), while distinct subsets were labeled with the $\beta 15$ and $\beta 22$ probes (Figures $7 \mathbf{B}, \mathbf{C}, \mathbf{E}, \mathbf{F}$ ) as well as the $\beta 3$, $\beta 16$, and $\beta 19$ probes (data not shown). These results indicated that each $P c d h-\beta$ gene isoform is expressed randomly and differentially in the peripheral nervous system (at least in the trigeminal and dorsal root ganglia).

To examine whether the $P c d h-\beta$ cluster genes showed randomscattered expression in GABAergic and cholinergic neurons, we performed double in situ hybridization analysis of the $P c d h-\beta$ genes with marker genes for GABAergic and cholinergic neurons. In the hippocampus, GABAergic interneurons constitute an inhibitory network that regulates excitatory neurons (Kullmann, 2011). The GABAergic interneurons were labeled with a GAD67 probe (Figures 8D-F) and showed strong labeling with the $P c d h-\beta$ highly conserved probe (Figures $\mathbf{8 A}, \mathbf{G}$ ). Distinct subsets of GABAergic interneurons were labeled with the $\beta 16$ and $\beta 22$ probes (Figures $\mathbf{8 B}, \mathbf{H}, \mathbf{C}, \mathbf{I}$ ). In the brain stem facial nucleus, cholinergic neurons, which were labeled with ChAT + VAChT probes (Figures 8L,M) (Arvidsson et al., 1997), showed prominent labeling by the $P c d h-\beta$ highly conserved probe (Figures 8J,N), and distinct subsets were labeled with the $\beta 16$ probe (Figures $\mathbf{8 K}, \mathbf{O}$ ). Taken together, these
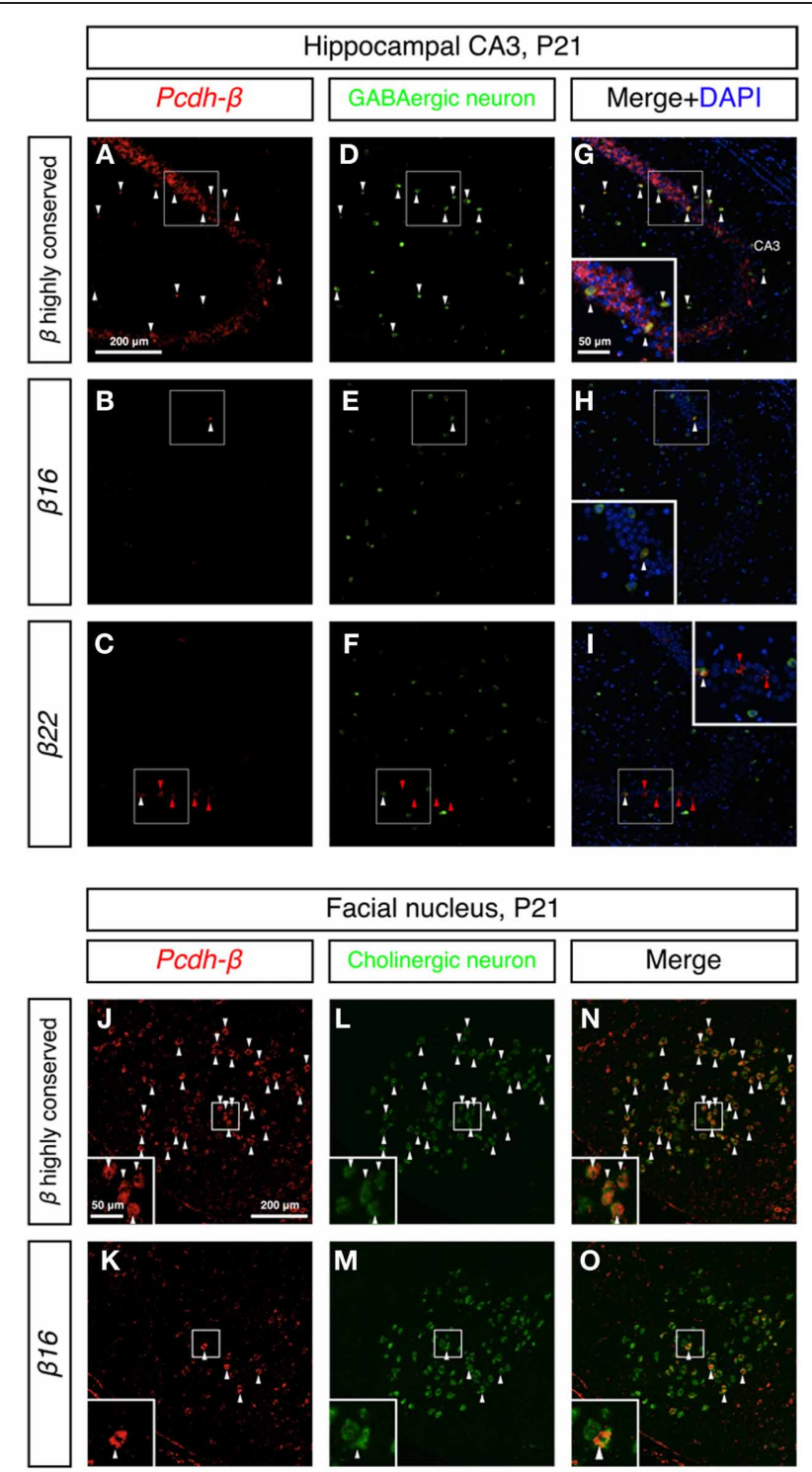

FIGURE 8 | Differential expression of $P c d h-\beta$ genes in GABAergic interneurons and cholinergic neurons. (A-I) Double in situ hybridization analysis of $P c d h-\beta$ genes (red: HNPP fluorescence) and GAD67 (green) in sagittal sections of P21 mouse hippocampus. (J-O) Double in situ hybridization analysis of $P c d h-\beta$ genes (red: false color of NBT/BCIP) and cholinergic neuron markers (ChAT + VAChT, green) in coronal sections of P21 mouse brain stem facial nucleus. Insets: High-magnification photomicrograph of the outlined area. Arrowheads indicate neurons expressing both Pcdh- $\beta$ and GAD67 or ChAT + VAChT mRNAs (white or black), and $\beta 22$ mRNA alone (red), respectively. Most neurons were stained by the $P c d h-\beta$ highly conserved probe, but the specific probes stained only subsets of these neurons, suggesting that each member of the $P c d h-\beta$ subfamily is expressed differentially in subpopulations of GABAergic interneurons in the hippocampus and cholinergic neurons in the facial nucleus.

results revealed that each member of the $P c d h-\beta$ cluster genes is expressed in a scattered pattern in a wide range of neuron types in the central and peripheral nervous systems in mouse. 


\section{DISCUSSION}

In this study, we extended previous analyses on how $P c d h$ genes contribute to single-neuron diversity, by examining the expression patterns of the $P c d h-\beta$ genes using in situ hybridization analysis and the newly developed single-cell $3^{\prime}$-RACE analysis. Our results revealed that the $P c d h-\beta$ isoforms showed randomlike scattered expression in both the central and the peripheral nervous systems, and that the $P c d h-\beta$ genes were regulated monoallelically and combinatorially in single Purkinje cells. We argue that the $P c d h-\alpha, P c d h-\beta$, and $P c d h-\gamma$ gene clusters confer unique molecular identities on individual neurons that could be responsible for appropriate neuronal circuit formation.

The newly developed split single-cell $3^{\prime}$-RACE method revealed that a variety of $3^{\prime}$-ends of $P c d h-\beta$ mRNAs could be expressed by a single Purkinje cell. There are numerous examples of genes with multiple polyadenylation signals, and the $3^{\prime}$ ends of their transcripts sometimes vary with the developmental stage or state of the tissue in which they are expressed (Edwalds-Gilbert et al., 1997). However, it is unclear if the variation in the $3^{\prime}$-ends of mRNAs is constant or changeable within a single cell during a single time-frame. The present study revealed that some of the $P c d h-\beta$ genes have more than two functional polyadenylation signals, and that the polyadenylation site can vary in a single cell. For example, in Cell \#2-10, three different variations of the $3^{\prime}$ end of $\beta 22$ were detected. Two of the three transcripts utilized the same polyadenylation signal, but the polyadenylation was added on a different nucleotide, while the other transcript utilized a different polyadenylation signal (Figure 5). This finding shows that even within a single cell the polyadenylation site can be variable, and suggests that the polyadenylation of the $3^{\prime}$ ends of $P c d h-\beta$ transcripts may be tightly or stochastically regulated.

A previous study detected the expression of several members of the $P c d h-\beta$ genes in mouse and human brain as a single exonic and 3 '-polyadenylated form (Vanhalst et al., 2001). Furthermore, several studies have reported the expression of $P c d h-\beta$ transcripts in the central nervous system including rat brain, rat hippocampus, and mouse retina (Sago et al., 1995; Schippert et al., 2009; McGowan et al., 2011). Our results confirm these findings and expand them to show that some, if not all, of the $22 P c d h-\beta$ genes are expressed in the central and peripheral nervous system, including the cerebellum, hippocampus, cerebral cortex, trigeminal ganglion, dorsal root ganglion, and brain stem.

Focusing on the individual $P c d h-\beta$ genes, our findings of random-like and combinatorial expression of the individual $P c d h-\beta$ genes extensively broaden the potential for $P c d h$-driven single-neuron diversity. The random-like scattered expression of individual $P c d h-\alpha$ and $P c d h-\gamma$ genes has been previously observed in olfactory bulb periglomerular neurons, hippocampal neurons, Purkinje cells, dorsal root ganglia neurons, and choroid plexus epithelial cells (Kohmura et al., 1998; Esumi et al., 2005; Frank et al., 2005; Kaneko et al., 2006; Prasad and Weiner, 2011; Lobas et al., 2012). In this study, we observed that individual $P c d h-\beta$ genes are expressed with a similar scattered pattern in cerebellar Purkinje cells, hippocampus, cerebral cortex, trigeminal ganglia, dorsal root ganglia, GABAergic interneurons, and cholinergic neurons. This pattern persisted during development, in that the random-like scattered expression of the $P c d h-\beta$ genes in cerebellar Purkinje cells was observed from P10 to P150. Furthermore, our data clearly showed that the individual $P c d h$ $\beta$ genes are regulated monoallelically and combinatorially in cerebellar Purkinje cells, similar to the $P c d h-\alpha$ and $P c d h-\gamma$ genes.

Our present results suggest that the individual $P c d h-\beta$ genes are differentially expressed among the various neuron types in the central and peripheral nervous systems from the juvenile to adult stages, and imply that the $P c d h-\beta$ gene cluster is regulated by similar mechanisms to the $P c d h-\alpha$ and $P c d h-\gamma$ genes. The similar genomic organization, involving multiple promoters with a conserved sequence element (CGCT), long-range enhancer element, and multiple CTCF-binding sites, supports this hypothesis (Wu et al., 2001; Ribich et al., 2006; Handoko et al., 2011; Yokota et al., 2011). To date, we have not found any rules governing the spatial distribution of the $P c d h-\beta$ transcripts; however it remains to be elucidated whether or not the pattern is truly random. One intriguing possibility is that the $P c d h-\beta$ expressional repertoires in individual neurons determine their target status during neural circuit formation; i.e., pre- and post-synaptic neurons might express the same sets of $P c d h-\beta$ genes. The present finding that Pcdh- $\beta$ genes show a scattered expression pattern on possible pre- and post-synaptic neurons in the hippocampal inhibitory interneuron network (Figures 6D-I and 8B,C,E,F,H,I) supports this idea.

The present study showed that the expression of the Pcdh- $\beta$ gene cluster is monoallelic and combinatorial in single Purkinje cells. This strongly suggests that individual Purkinje cells express a variable repertoire of some, if not all, of the $22 P c d h-\beta$ genes. In this study, we investigated six of the $22 P c d h-\beta$ genes and showed that at least two types of $P c d h-\beta$ per allele can be expressed by a single Purkinje cell (see $\beta 9$ and $\beta 19$ in Cell $\# 1-17$, and $\beta 3$ and $\beta 9$ in Cell \#2-22). The variety of $P c d h-\beta$ species expressed by a single Purkinje cell can be extrapolated from the present results. In the experiments shown in Figures 3 and 4, among the 28 Purkinje cells analyzed, in 18 of them, one or more clear bands representing the PCR product were obtained from all three split tubes $(\beta 10$ in Cell \#1-1, $\beta 15$ in Cell \#1-2, $\beta 19$ in Cell \#1-5, $\beta 9$ in Cell \#1-7, $\beta 9$ and $\beta 19$ in Cell $\# 1-10, \beta 19$ in Cell $\# 1-11, \beta 3$ and $\beta 22$ in Cell $\# 1-12, \beta 3$ in Cell $\# 1-14, \beta 9$ and $\beta 19$ in Cell $\# 1-17, \beta 15$ in Cell \#1-22, $\beta 15$ in Cell \#1-26, $\beta 10$ in Cell \#1-28, $\beta 9$ from biallelic expression in Cell \#1-36, $\beta 19$ in Cell \#1-39). Therefore, 0.64 (18/28) Pcdh- $\beta$ genes were expressed per Purkinje cell. Assuming that there is no distortion of expression frequencies between isoforms, and given that there are 22 genes in the $P c d h-\beta$ cluster, we can estimate that $2.3 P c d h-\beta$ genes ( 0.64 multiplied by $22 / 6$ ) should be expressed per individual Purkinje cell. Thus, at least two $P c d h-\beta$ isoforms would be expressed by any given Purkinje cell. If these assumptions prove correct, the $P c d h-\beta$ transcripts could, in theory, produce more than $462(22 \times 21)$ possible combinations (one Pcdh- $\beta$ isoform from each allele) in single Purkinje cells.

The combinatorial co-expression of the mouse Pcdh cluster genes, including the $P c d h-\alpha, P c d h-\beta$, and $P c d h-\gamma$ genes, could provide diversity sufficient to represent more than 20 million unique Purkinje cells, among which $P c d h-\alpha$ transcripts could produce $132(12 \times 11)$ possible combinations (one Pcdh- $\alpha$ isoform from each allele), $P c d h-\beta$ transcripts could produce $462(22 \times 21)$ 
possible combinations (one $P c d h-\beta$ isoform from each allele), and $P c d h-\gamma$ transcripts could produce $342(19 \times 18)$ possible combinations (one $P c d h-\gamma$ isoform from each allele). Interestingly, rats have about 500 thousand cerebellar Purkinje cells, and humans have 14 million (Ito, 1984). Thus, the possible combinations of $P c d h$ cluster gene expressions would be sufficient to distinguish each cell.

The hypothesis that the Pcdh cluster genes play roles in providing cell-surface diversity is supported by reports that showed synaptic and surface localization of the Pcdh- $\alpha$, Pcdh- $\beta$, and Pcdh- $\gamma$ proteins and their formation of multimeric complexes (Kohmura et al., 1998; Wang et al., 2002b; Murata et al., 2004; Junghans et al., 2008; Chen et al., 2009; Fernandez-Monreal et al., 2009; Han et al., 2010; Puller and Haverkamp, 2011). Schreiner and Weiner (2010) showed that seven Pcdh- $\gamma$ members exhibit isoform-specific homophilic binding, and that heteromultimeric cis-tetramers function as a homophilic binding unit. Although whether heteromultimeric cis-tetramers include Pcdh- $\beta$ proteins is unclear, it is an intriguing possibility that heteromultimeric cis-tetramers with Pcdh- $\beta$ proteins extend the homophilic binding specificity and play important roles in neural circuit formation.

This scenario could be supported by the following two findings. First, Pcdh- $\beta$ proteins associate with $\mathrm{Pcdh}-\gamma$ proteins (Han et al., 2010). Second, the Cys-(X)5-Cys (C-X5-C) motif is important for the formation and cell-surface expression of covalently bound cis-tetramers, and the $\mathrm{C}-\mathrm{X} 5-\mathrm{C}$ motif in the EC1 domain is completely conserved among all clustered Pcdh proteins in vertebrates (Schreiner and Weiner, 2010; Yagi, 2012). Our group plans to examine the formation of heteromultimeric cis-tetramers that include Pcdh- $\beta$ proteins and their binding activities.

The importance of highly diverse transmembrane molecules in the formation of neuronal circuits has been shown in Drosophila, where Dscam 1 molecules are responsible for the correct patterning of neuronal circuits (Hattori et al., 2007, 2008; Schmucker and Chen, 2009). We therefore speculate that the requirement for

\section{REFERENCES}

Arvidsson, U., Riedl, M., Elde, R., and Meister, B. (1997). Vesicular acetylcholine transporter (VAChT) protein: a novel and unique marker for cholinergic neurons in the central and peripheral nervous systems. $J$. Comp. Neurol. 378, 454-467.

Castillo, S. D., Matheu, A., Mariani, N., Carretero, J., Lopez-Rios, F., LovellBadge, R., and Sanchez-Cespedes, M. (2012). Novel transcriptional targets of the SRY-HMG box transcription factor SOX4 link its expression to the development of small cell lung cancer. Cancer Res. 72, 176-186.

Chahrour, M., Jung, S. Y., Shaw, C., Zhou, X., Wong, S. T., Qin, J., and Zoghbi, H. Y. (2008). $\mathrm{MeCP} 2$, a key contributor to

single-neuron diversity in neural circuit formation is conserved from insects to vertebrates, and that the Pcdh cluster is responsible for this role in the vertebrate nervous system (Zipursky and Sanes, 2010; Yagi, 2012). Future studies aimed at testing this hypothesis could shed light on the fundamental mechanisms underlying vertebrate neural circuit formation.

\section{ACKNOWLEDGMENTS}

We thank Dr. T. Shiroishi and The National Institute of Genetics for providing the JF1 strain, and members of the laboratory of Takeshi Yagi for suggestions and discussions during the course of this work. We appreciate Mses. C. Choji, K. Shimazu, H. Masuda, Y. Hidaka, A. Kinjo, E. Naruto, M. Katagiri, and A. Morita for their technical support, and Ms. H. Morita for her excellent secretarial assistance. This work was supported by Grant-in-Aid for Young Scientists (B) (JSPS) (No. 19770147, 22700326), and the Life Science Foundation of Japan (Ryosuke Kaneko), and Grant-in-Aid for Scientific Research (S) (JSPS) (No. 19100006), Innovative Areas "Mesoscopic Neurocircuitry" (No. 23115513) and (Comprehensive Brain Science Network) from the Ministry of Education, Science, Sports, and Culture of Japan (MEXT), JSTCREST, and the Uehara Memorial Foundation, and the Takeda Foundation (Takeshi Yagi).

\section{SUPPLEMENTARY MATERIAL}

The Supplementary Material for this article can be found online at http://www.frontiersin.org/Molecular_Neuroscience/10.3389/ fnmol.2012.00090/abstract

FIGURE S1 | Partial sequence, of a region close to the 3-polyadenylated site, of some of the $\boldsymbol{P c d h} \boldsymbol{\beta} \boldsymbol{\beta}$ genes analyzed in this study. We found 27 polymorphisms (indicated by a yellow background) that enabled us to distinguish whether the amplified product was from the B6 or JF1 chromosome. The putative polyadenylation signal sequences are shown in red-underlined letters.

\section{Table S1 | List of primers.}

Table S2 | The possible poly adenylation signals of some of the Pcdh- $\beta$ transcripts.

clusters on chromosome $5 \mathrm{q} 31$ in Wilms' tumor. PLoS Genet. 5, e1000745.

neurological disease, activates represses transcription. Science 320 1224-1229.

Chen, J., Lu, Y., Meng, S., Han, M. H., Lin, C., and Wang, X. (2009). alphaand gamma-Protocadherins negatively regulate PYK2. J. Biol. Chem. 284, 2880-2890.

Chess, A. (2005). Monoallelic expression of protocadherin genes. Nat. Genet. 37, 120-121.

Dallosso, A. R., Hancock, A. L., Szemes, M., Moorwood, K., Chilukamarri, L., Tsai, H. H., Sarkar, A., Barasch, J., Vuononvirta, R., Jones, C., Pritchard-Jones, K., Royer-Pokora, B., Lee, S. B., Owen, C., Malik, S., Feng, Y., Frank, M., Ward, A., Brown, K. W., and Malik, K. (2009). Frequent long-range epigenetic silencing of protocadherin gene
Dallosso, A. R., Oster, B., Greenhough, A., Thorsen, K., Curry, T. J., Owen, C., Hancock, A. L., Szemes, M., Paraskeva, C., Frank, M., Andersen, C. L., and Malik, K. (2012). Long-range epigenetic silencing of chromosome $5 \mathrm{q} 31$ protocadherins is involved in early and late stages of colorectal tumorigenesis through modulation of oncogenic pathways. Oncogene. doi: 10.1038/onc.2011.609. [Online].

Edwalds-Gilbert, G., Veraldi, K. L., and Milcarek, C. (1997). Alternative plex transcription units: means to an end? Nucleic Acids Res. 25, 2547-2561. poly(A) site selection in com-
Esumi, S., Kakazu, N., Taguchi, Y., Hirayama, T., Sasaki, A., Hirabayashi, T., Koide, T., Kitsukawa, T., Hamada, S., and Yagi, T. (2005). Monoallelic yet combinatorial expression of variable exons of the protocadherinalpha gene cluster in single neurons. Nat. Genet. 37, 171-176.

Esumi, S., Kaneko, R., Kawamura, Y., and Yagi, T. (2006). Split single-cell RT-PCR analysis of Purkinje cells. Nat. Protoc. 1, 2143-2151.

Fernandez-Monreal, M., Kang, S., and Phillips, G. R. (2009). Gamma-protocadherin homophilic interaction and intracellular trafficking is controlled by the cytoplasmic domain in neurons. Mol. Cell. Neurosci. 40, 344-353. 
Frank, M., Ebert, M., Shan, W., Phillips, G. R., Arndt, K., Colman, D. R., and Kemler, R. (2005). Differential expression of individual gammaprotocadherins during mouse brain development. Mol. Cell. Neurosci. $29,603-616$.

Fukuda, E., Hamada, S., Hasegawa, S., Katori, S., Sanbo, M., Miyakawa, T., Yamamoto, T., Yamamoto, H., Hirabayashi, T., and Yagi, T. (2008). Down-regulation of protocadherinalpha $\mathrm{A}$ isoforms in mice changes contextual fear conditioning and spatial working memory. Eur. J. Neurosci. 28, 1362-1376.

Golan-Mashiach, M., Grunspan, M., Emmanuel, R., Gibbs-Bar, L., Dikstein, R., and Shapiro, E. (2012). Identification of CTCF as a master regulator of the clustered protocadherin genes. Nucleic Acids Res. 40, 3378-3391.

Han, M. H., Lin, C., Meng, S., and Wang, X. (2010). Proteomics analysis reveals overlapping functions of clustered protocadherins. Mol. Cell. Proteomics 9, 71-83.

Handoko, L., Xu, H., Li, G., Ngan, C. Y., Chew, E., Schnapp, M., Lee, C. W., Ye, C., Ping, J. L., Mulawadi, F., Wong, E., Sheng, J., Zhang, Y., Poh, T., Chan, C. S., Kunarso, G., Shahab, A., Bourque, G., Cacheux-Rataboul, V., Sung, W. K., Ruan, Y., and Wei, C. L. (2011). CTCF-mediated functional chromatin interactome in pluripotent cells. Nat. Genet. 43, 630-638.

Hasegawa, S., Hamada, S., Kumode, Y., Esumi, S., Katori, S., Fukuda, E., Uchiyama, Y., Hirabayashi, T., Mombaerts, P., and Yagi, T. (2008). The protocadherin-alpha family is involved in axonal coalescence of olfactory sensory neurons into glomeruli of the olfactory bulb in mouse. Mol. Cell Neurosci. 38, 66-79.

Hattori, D., Demir, E., Kim, H. W., Viragh, E., Zipursky, S. L., and Dickson, B. J. (2007). Dscam diversity is essential for neuronal wiring and self-recognition. Nature 449, 223-227.

Hattori, D., Millard, S. S., Wojtowicz, W. M., and Zipursky, S. L. (2008). Dscam-mediated cell recognition regulates neural circuit formation. Annu. Rev. Cell Dev. Biol. 24, 597-620.

Hirayama, T., Tarusawa, E., Yoshimura, Y., Galjart, N., and Yagi, T. (2012). CTCF is required for neural development and stochastic expression of clustered Pcdh genes in neurons. Cell Rep. doi: 10.1016/j.celrep. 2012.06.014. [Online].

Hirayama, T., and Yagi, T. (2006). The role and expression of the protocadherin-alpha clusters in the CNS. Curr. Opin. Neurobiol. 16, 336-342.

Ito, M. (1984). The Cerebellum and Neural Control. New York, NY: Raven Press.

Junghans, D., Heidenreich, M., Hack, I., Taylor, V., Frotscher, M., and Kemler, R. (2008). Postsynaptic and differential localization to neuronal subtypes of protocadherin beta 16 in the mammalian central nervous system. Eur. J. Neurosci. 27, 559-571.

Kaneko, R., Kato, H., Kawamura, Y., Esumi, S., Hirayama, T., Hirabayashi, T., and Yagi, T. (2006). Allelic gene regulation of Pcdh-alpha and Pcdh-gamma clusters involving both monoallelic and biallelic expression in single Purkinje cells. J. Biol. Chem. 281, 30551-30560.

Kaneko, R., Kawaguchi, M., Toyama, T., Taguchi, Y., and Yagi, T. (2009). Expression levels of Protocadherinalpha transcripts are decreased by nonsense-mediated mRNA decay with frameshift mutations and by high DNA methylation in their promoter regions. Gene 430, 86-94.

Katori, S., Hamada, S., Noguchi, Y., Fukuda, E., Yamamoto, T., Yamamoto, H., Hasegawa, S., and Yagi, T. (2009). Protocadherinalpha family is required for serotonergic projections to appropriately innervate target brain areas. J. Neurosci. 29, 9137-9147.

Kawaguchi, M., Toyama, T., Kaneko, R., Hirayama, T., Kawamura, Y., and Yagi, T. (2008). Relationship between DNA methylation states and transcription of individual isoforms encoded by the protocadherin-alpha gene cluster. $J$. Biol. Chem. 283, 12064-12075.

Kawauchi, S., Calof, A. L., Santos, R., Lopez-Burks, M. E., Young, C. M., Hoang, M. P., Chua, A., Lao, T., Lechner, M. S., Daniel, J. A., Nussenzweig, A., Kitzes, L., Yokomori, K., Hallgrimsson, B., and Lander, A. D. (2009). Multiple organ system defects and transcriptional dysregulation in the $\mathrm{Nipbl}(+/-)$ mouse, a model of Cornelia de Lange Syndrome. PLoS Genet. 5:e1000650. doi: 10.1371/journal.pgen.1000650

Kehayova, P., Monahan, K., Chen, W., and Maniatis, T. (2011). Regulatory elements required for the activation and repression of the protocadherin-alpha gene cluster. Proc. Natl. Acad. Sci. U.S.A. 108, 17195-17200.

Kohmura, N., Senzaki, K., Hamada, S., Kai, N., Yasuda, R., Watanabe, M., Ishii, H., Yasuda, M., Mishina,
M., and Yagi, T. (1998). Diversity revealed by a novel family of cadherins expressed in neurons at a synaptic complex. Neuron 20, 1137-1151.

Kullmann, D. M. (2011). Interneuron networks in the hippocampus. Curr. Opin. Neurobiol. 21, 709-716.

Lobas, M. A., Helsper, L., Vernon, C. G., Schreiner, D., Zhang, Y., Holtzman, M. J., Thedens, D. R., and Weiner, J. A. (2012). Molecular heterogeneity in the choroid plexus epithelium: the 22-member gamma-protocadherin family is differentially expressed, apically localized, and implicated in CSF regulation. J. Neurochem. 120, 913-927.

McGowan, P. O., Suderman, M., Sasaki, A., Huang, T. C., Hallett, M., Meaney, M. J., and Szyf, M. (2011). Broad epigenetic signature of maternal care in the brain of adult rats. PLoS ONE 6:e14739. doi: 10.1371/journal.pone.0014739

Miyake, K., Hirasawa, T., Soutome, M., Itoh, M., Goto, Y., Endoh, K., Takahashi, K., Kudo, S., Nakagawa, T., Yokoi, S., Taira, T., Inazawa, J., and Kubota, T. (2011). The protocadherins, PCDHB1 and PCDH7, are regulated by $\mathrm{MeCP} 2$ in neuronal cells and brain tissues: implication for pathogenesis of Rett syndrome. BMC Neurosci. 12, 81 .

Monahan, K., Rudnick, N. D., Kehayova, P. D., Pauli, F., Newberry, K. M., Myers, R. M., and Maniatis, T. (2012). Role of CCCTC binding factor (CTCF) and cohesin in the generation of single-cell diversity of protocadherin-alpha gene expression. Proc. Natl. Acad. Sci. U.S.A. 109, 9125-9130.

Morishita, H., and Yagi, T. (2007). Protocadherin family: diversity, structure, and function. Curr. Opin. Cell Biol. 19, 584-592.

Murata, Y., Hamada, S., Morishita, H., Mutoh, T., and Yagi, T. (2004). Interaction with protocadheringamma regulates the cell surface expression of protocadherin-alpha. J. Biol. Chem. 279, 49508-49516.

Neves, G., Zucker, J., Daly, M., and Chess, A. (2004). Stochastic yet biased expression of multiple Dscam splice variants by individual cells. Nat. Genet. 36, 240-246.

Noguchi, Y., Hirabayashi, T., Katori, S., Kawamura, Y., Sanbo, M., Hirabayashi, M., Kiyonari, H., Nakao, K., Uchimura, A., and Yagi, T. (2009). Total expression and dual gene-regulatory mechanisms maintained in deletions and duplications of the Pcdha cluster. J. Biol. Chem. 284, 32002-32014.
Prasad, T., and Weiner, J. A. (2011). Direct and indirect regulation of spinal cord Ia afferent terminal formation by the gammaprotocadherins. Front. Mol. Neurosci. 4:54. doi: 10.3389/ fnmol.2011.00054

Puller, C., and Haverkamp, S. (2011). Cell-type-specific localization of protocadherin betal6 at AMPA and AMPA/Kainate receptorcontaining synapses in the primate retina. J. Comp. Neurol. 519, 467-479.

Rhoades, K. L., Singh, N., Simon, I., Glidden, B., Cedar, H., and Chess, A. (2000). Allele-specific expression patterns of interleukin-2 and Pax5 revealed by a sensitive singlecell RT-PCR analysis. Curr. Biol. 10, 789-792.

Ribich, S., Tasic, B., and Maniatis, T. (2006). Identification of longrange regulatory elements in the protocadherin-alpha gene cluster. Proc. Natl. Acad. Sci. U.S.A. 103, 19719-19724.

Sago, H., Kitagawa, M., Obata, S., Mori, N., Taketani, S., Rochelle, J. M., Seldin, M. F., Davidson, M., St John, T., and Suzuki, S. T. (1995). Cloning, expression, and chromosomal localization of a novel cadherin-related protein, protocadherin-3. Genomics 29, 631-640.

Schippert, R., Schaeffel, F., and Feldkaemper, M. P. (2009). Microarray analysis of retinal gene expression in Egr-1 knockout mice. Mol. Vis. 15, 2720-2739.

Schmucker, D., and Chen, B. (2009). Dscam and DSCAM: complex genes in simple animals, complex animals yet simple genes. Genes Dev. 23, 147-156.

Schreiner, D., and Weiner, J. A. (2010). Combinatorial homophilic interaction between gammaprotocadherin multimers greatly expands the molecular diversity of cell adhesion. Proc. Natl. Acad. Sci. U.S.A. 107, 14893-14898.

Sugino, H., Hamada, S., Yasuda, R., Tuji, A., Matsuda, Y., Fujita, M., and Yagi, T. (2000). Genomic organization of the family of CNR cadherin genes in mice and humans. Genomics 63, 75-87.

Suzuki, S. C., and Takeichi, M. (2008). Cadherins in neuronal morphogenesis and function. Dev. Growth Differ. 50(Suppl. 1), S119-S130.

Takeichi, M. (2007). The cadherin superfamily in neuronal connections and interactions. Nat. Rev. Neurosci. 8, 11-20.

Tan, Y. P., Li, S., Jiang, X. J., Loh, W., Foo, Y. K., Loh, C. B., Xu, Q., Yuen, 
W. H., Jones, M., Fu, J., Venkatesh, B., and Yu, W. P. (2010). Regulation of protocadherin gene expression by multiple neuron-restrictive silencer elements scattered in the gene cluster. Nucleic Acids Res. 38, 4985-4997.

Tasic, B., Nabholz, C. E., Baldwin, K. K., Kim, Y., Rueckert, E. H., Ribich, S. A., Cramer, P., Wu, Q., Axel, R., and Maniatis, T. (2002). Promoter choice determines splice site selection in protocadherin alpha and gamma pre-mRNA splicing. Mol. Cell 10, 21-33.

Vanhalst, K., Kools, P., Vanden Eynde, E., and van Roy, F. (2001). The human and murine protocadherinbeta one-exon gene families show high evolutionary conservation, despite the difference in gene number. FEBS Lett. 495, 120-125.

Wang, X., Su, H., and Bradley, A. (2002a). Molecular mechanisms governing Pcdh-gamma gene expression: evidence for a multiple promoter and cis-alternative splicing model. Genes Dev. 16, 1890-1905.

Wang, X., Weiner, J. A., Levi, S., Craig, A. M., Bradley, A., and Sanes, J. R. (2002b). Gamma protocadherins are required for survival of spinal interneurons. Neuron 36, 843-854.

Watakabe, A., Ichinohe, N., Ohsawa, S., Hashikawa, T., Komatsu, Y., Rockland, K. S., and Yamamori, T. (2007). Comparative analysis of layer-specific genes in Mammalian neocortex. Cereb. Cortex 17, 1918-1933.

Watakabe, A., Komatsu, Y., Ohsawa, S., and Yamamori, T. (2010). Fluorescent in situ hybridization technique for cell type identification and characterization in the central nervous system. Methods 52, 367-374.

Wu, Q., and Maniatis, T. (1999). A striking organization of a large family of human neural cadherinlike cell adhesion genes. Cell 97, 779-790.

Wu, Q., Zhang, T., Cheng, J. F., Kim, Y., Grimwood, J., Schmutz, J., Dickson,
M., Noonan, J. P., Zhang, M. Q., Myers, R. M., and Maniatis, T. (2001). Comparative DNA sequence analysis of mouse and human protocadherin gene clusters. Genome Res. 11, 389-404.

Yagi, T. (2008). Clustered protocadherin family. Dev. Growth Differ. 50(Suppl. 1), S131-S140.

Yagi, T. (2012). Molecular codes for neuronal individuality and cell assembly in the brain. Front. Mol. Neurosci. 5:45. doi: 10.3389/ fnmol.2012.00045

Yokota, S., Hirayama, T., Hirano, K., Kaneko, R., Toyoda, S., Kawamura, Y., Hirabayashi, M., Hirabayashi, T., and Yagi, T. (2011). Identification of the cluster control region for the Protocadherin-\{beta\} genes located beyond the Protocadherin\{gamma\} cluster. J. Biol. Chem. 286, 31886-31895

Zipursky, S. L., and Sanes, J. R. (2010). Chemoaffinity revisited: dscams, protocadherins, and neural circuit assembly. Cell 143, 343-353.
Conflict of Interest Statement: The authors declare that the research was conducted in the absence of any commercial or financial relationships that could be construed as a potential conflict of interest.

Received: 20 July 2012; paper pending published: 09 August 2012; accepted: 14 August 2012; published online: 31 August 2012.

Citation: Hirano K, Kaneko R, Izawa T, Kawaguchi M, Kitsukawa $T$ and Yagi $T$ (2012) Single-neuron diversity generated by Protocadherin- $\beta$ cluster in mouse central and peripheral nervous systems. Front. Mol. Neurosci. 5:90. doi: 10.3389/ fnmol.2012.00090

Copyright (c) 2012 Hirano, Kaneko, Izawa, Kawaguchi, Kitsukawa and Yagi. This is an open-access article distributed under the terms of the Creative Commons Attribution License, which permits use, distribution and reproduction in other forums, provided the original authors and source are credited and subject to any copyright notices concerning any third-party graphics etc. 